$7^{\text {th }}$ International Workshop

\title{
Modelling Nutrient Digestion and Utilization in Farm Animals
}

Paris, $10^{\text {th }}-12^{\text {th }}$ September 2009

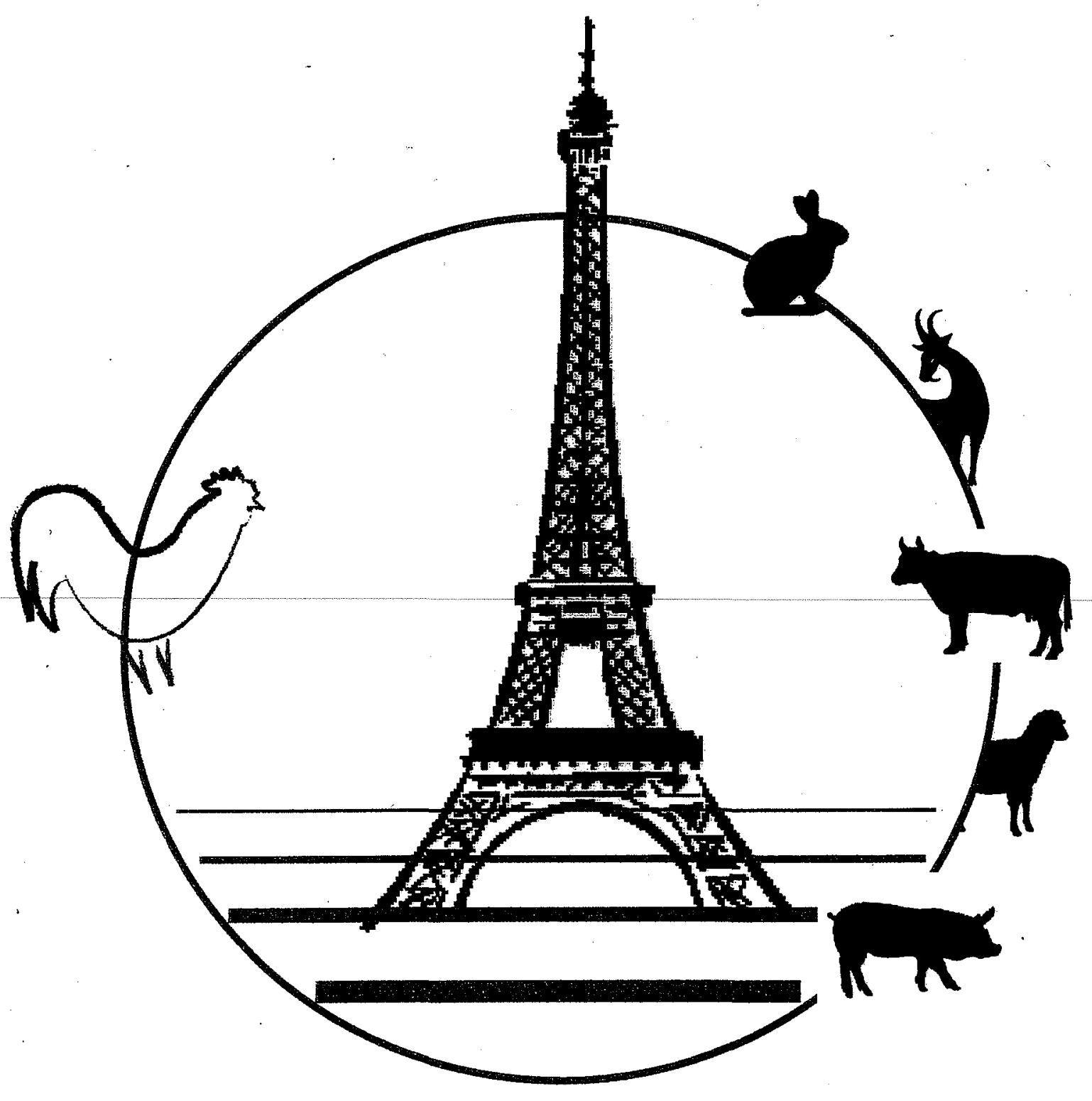




\section{NUTRITION-GENETICS INTERACTION IN NUTRIENT UTILISATION OF CANOLA AND LUPINS BY AUSTRALIAN SHEEP: PREDICTION OF WOOL FIBRE DIAMETER}

A.E.O. Malau-Aduli, R.E. Walker, C.F. Ranson, J.M. Sykes and W.C. Bignell

Animal Production and Genetics, School of Agricultural Science, University of Tasmania, Private Bag 54 Hobart, Tasmania 7001, Australia.

"Corresponding author: Aduli.MalauAduli@utas.edu.au, Tel: +61-3-6226-2717, Fax: +61-3-6226-2642

High digestibility and nutrient retention of feed on offer are important indices of protein and energy available for wool fibre synthesis or muscle accretion in sheep. The Australian national flock is predominantly based on Merino crossbreds (Fogarty et al. 2005a) where the prime lamb industry exploits crossbreeding in which $40 \%$ of the annual slaughter of about 18 million lambs is first-cross progeny from terminal sire rams mated to Merino ewes (Fogarty et al., 2005b). Utilisation of predictive models based on digestibility of protein and energy in sheep would be useful in estimating valuable quality traits such as fibre diameter since wool is a bonus in the prime lamb production sector whose primary product is meat. Our objective in this study was to investigate the interactions between sire breed and supplement on digestibility and to ascertain its accuracy in predicting wool fibre diameter.

Forty first-cross Merino weaner sheep sired by Texel, Coopworth, White Suffolk, East-Friesian and Dorset sires with initial BW range of 22.9 and $31.3 \mathrm{~kg}$ (average of $26.8 \pm 3.2 \mathrm{~kg}$ ) were randomly assigned to four treatment groups in a $5 \times 2 \times 2 \times 2$ factorial experimental design representing 5 sire breeds, 2 supplementary feeds (canola and lupins), 2 feeding levels ( 1 and $2 \%$ of bodyweight) and 2 sexes (ewes and wethers). The feeding trial lasted for six weeks with an initial 3-week adjustment period and the last 7 days for faecal collection. Factorial ANOVA with orthogonal contrasts in SAS was used for statistical analysis to test for the interactions between sire breed and supplement on digestibility and wool fibre diameter. We also utilised both linear and non-linear regressions in modelling the predictive accuracy of fibre diameter from digestibility coefficients.

Our results demonstrated that sire breed $x$ level of feeding interactions significantly influenced digestibility $(P<0.01)$ whereby Coopworth-sired sheep supplemented at $1 \%$ of their body weight recorded the highest metabolisable energy (ME) and protein ( $N$ ) digestibility of $54 \%$ and $67 \%$ compared to $42 \%$ and $62 \%$ respectively, in their counterparts fed at $2 \%$ of body weight. There was a highly significant $(P<0.01)$ effect of type of supplement $x$ level of feeding interaction on wool fibre diameter at the end of the trial because sheep fed canola supplements at $1 \%$ of body weight had finer wool (22.1 microns) than their $2 \%$-fed counterparts (25.4 microns). Regression of wool fibre diameter on digestibility revealed very poor prediction accuracy $\left(R^{2}=0.0087-0.169\right)$. We concluded that sire breed variation in digestibility is unlikely to be a useful predictor of genetic merit for wool fibre diameter in first cross sheep under the same management.

Fogarty NM, Ingham VM, Gilmour AR, Cummins LJ, Gaunt GM, Stafford J, Hocking Edwards JE, Banks RG (2005a). Genetic evaluation of crossbred lamb production 1. Breed and fixed effects for birth and weaning weight of first-cross lambs, gestation length and reproduction of base ewes. Australian Joumal of Agnicultural Research 56: 443-453.

Fogarty NM, Ingham VM, Gilmour AR, Cummins LJ, Gaunt GM, Stafford J, Hocking Edwards JE, Banks RG (2005b). Genetic evaluation of crossbred lamb production 2. Breed and fixed effects for post-weaning growth, carcass and wool of first-cross lambs. Australian Joumal of Agricultural Research 56: 455-463. 